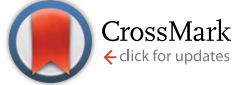

Cite this: J. Mater. Chem. A, 2014, 2 , 15904

Received 29th June 2014 Accepted 28th July 2014

DOI: $10.1039 / c 4 t a 03314 k$

www.rsc.org/MaterialsA

\section{High efficiency solution-processed two- dimensional small molecule organic solar cells obtained via low-temperature thermal annealing $\dagger$}

\author{
Zhengkun Du, ${ }^{\text {ab }}$ Weichao Chen, ${ }^{a}$ Yanhua Chen, ${ }^{\text {ac }}$ Shanlin Qiao, ${ }^{a}$ Xichang Bao, ${ }^{a}$ \\ Shuguang Wen, ${ }^{a}$ Mingliang Sun, ${ }^{c}$ Liangliang $\mathrm{Han}^{\mathrm{a}}$ and Renqiang Yang*a
}

\begin{abstract}
A new two-dimensional (2D) organic small molecule, DCA3T(T-BDT), was designed and synthesized for solution-processed organic solar cells (OSCs). DCA3T(T-BDT) exhibited a deep HOMO energy level $(-5.37 \mathrm{eV})$ and good thermal stability. The morphologies of the DCA3T(T-BDT):[6,6]-phenyl-C61-butyric acid methyl ester $\left(\mathrm{PC}_{61} \mathrm{BM}\right)$ blends were investigated by atomic force microscopy and the crystallinity was explored by X-ray diffraction (XRD) and 2D grazing incidence wide-angle X-ray scattering (GIWAXS), respectively. The morphologies of the blends were strongly influenced by the blend ratio of DCA3T(T$B D T): P C_{61} B M$ and annealing temperature. The effect of thermal annealing on the photovoltaic performance of DCA3T(T-BDT)-based small molecule organic solar cells (SMOSCS) was studied in detail. When DCA3T(T-BDT) was used as a donor with $\mathrm{PC}_{61} \mathrm{BM}$ as an acceptor, high efficiency SMOSCs with a power conversion efficiency of $7.93 \%$, a high $V_{\text {oc }}$ of $0.95 \mathrm{~V}, \mathrm{~J}_{\mathrm{sc}}$ of $11.86 \mathrm{~mA} \mathrm{~cm} \mathrm{~cm}^{-2}$ and $\mathrm{FF}$ of 0.70 were obtained by a thermal annealing process at only $60{ }^{\circ} \mathrm{C}$, which offers obvious advantages for large scale production compared with solvent additive or interfacial modification treatment.
\end{abstract}

\section{Introduction}

Over the past two decades, organic solar cells (OSCs) as a promising renewable energy source have attracted considerable attention of chemical, material and physical scientists because of their low cost, light weight, and large area fabrication on flexible substrates. ${ }^{1-9}$ At present, the power conversion efficiency (PCE) of bulk heterojunction (BHJ) OSCs based on low band gap conjugated polymer is over $9 \%$ using an inverted device architecture. ${ }^{10}$ As an alternative candidate for polymer solar cells, small molecule organic solar cells (SMOSCs) have recently achieved great development, and PCE of over $8 \%$ have been realized through carefully modifying the molecular structure and using additives. ${ }^{\mathbf{1 1} 12}$ Although PCE is still relatively lower than that of polymer solar cells, SMOSCs have a better prospect of industrialization due to their unique advantages of welldefined molecular structure, synthetic reproducibility, monodispersity, and convenient energy level control. ${ }^{13-22}$ Thus, further work on designing new small molecules and gaining a

${ }^{a}$ CAS Key Laboratory of Bio-based Materials, Qingdao Institute of Bioenergy and Bioprocess Technology, Chinese Academy of Sciences, Qingdao 266101, China. E-mail: yangrq@qibebt.ac.cn

${ }^{b}$ University of Chinese Academy of Sciences, Beijing 100049, China

${ }^{c}$ Institute of Materials Science and Engineering, Ocean University of China, Qingdao 266100, China

$\dagger$ Electronic supplementary information (ESI) available. See DOI: $10.1039 / \mathrm{c} 4 \mathrm{ta} 03314 \mathrm{k}$ better understanding of the molecular structure-function relationships are needed for their future commercial applications.

Compared to their polymeric counterparts, ${ }^{23-25}$ in most cases, SMOSCs have relatively low fill factor (FF) and short circuit current density $\left(J_{\mathrm{sc}}\right)$ due to their poorer film formation ability and this has become the main hindrance for developing high performance devices. ${ }^{26}$ To date, conjugated organic small molecules with wide absorption, high hole mobility, as well as appropriate miscibility with the fullerene acceptor to form uniform interpenetrating networks were designed and synthesized for high efficiency SMOSCs. ${ }^{17,27}$ Among the vast variety of the developed electron-donating materials for OSCs, twodimensional (2D) alkylthiophene substituted benzo[1,2- $\left.b: 4,5-b^{\prime}\right]$ dithiophene (BDT) has been proved to be a promising material for photovoltaic applications. ${ }^{28-30}$ The incorporation of thiophene side chains could extend the vertical $\pi-\pi$ conjugation and promote $\pi-\pi$ stacking in the solid state. ${ }^{31}$ This extended conjugated structure is beneficial in improving charge transport and correspondingly achieve a high $J_{\mathrm{sc}}{ }^{31,32}$ Compared with a one-dimensional (1D) BDT-based conjugated polymer, ${ }^{6}$ the $2 \mathrm{D}$ BDT-based polymer generally represents a higher open-circuit voltage $\left(V_{\text {oc }}\right)$ in the organic solar cell due to its lower highest occupied molecular orbital (HOMO) levels..33,34 Hou et al. reported a series of copolymers based on 2D BDT derivatives, which showed excellent photovoltaic performance with PCEs of over $7 \% .^{31,35}$ Considering the great progress that has been achieved in polymer OSCs using 2D BDT derivatives, the 2D BDT unit is a promising donor material for SMOSCs. ${ }^{12,15,36}$ Therefore, 


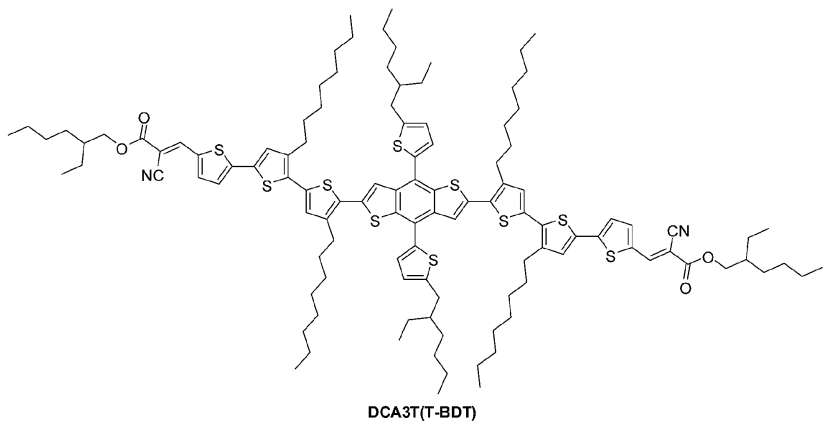

Scheme 1 Chemical structure of DCA3T(T-BDT).

novel small molecules with high efficiency would be designed and synthesized if the HOMO and LUMO levels of the 2D BDTbased small molecules could be effectively tuned by employing appropriate electron-withdrawing groups. On the other hand, a suitable method for fabricating the organic solar cells is also crucial for achieving high efficiency. Thermal annealing of BHJ films is one of the most widely used methods for improving the $J_{\mathrm{sc}}$ and $\mathrm{FF}$ of BHJ OSCs. ${ }^{37-40}$ However, as the thermal annealing temperature increases, the $V_{\text {oc }}$ of SMOSCs sometimes significantly decreases..$^{38}$ Given the effect of thermal annealing on the morphology and crystallinity of the film, a delicate balance between $V_{\mathrm{oc}}, J_{\mathrm{sc}}$ and FF could be achieved by annealing at a low temperature, and a maximum PCE of solution-processed SMOSCs will be achieved.

In view of the aforementioned concerns, we have successfully synthesized a new solution-processed 2D-conjugated organic small molecule, DCA3T(T-BDT) (Scheme 1), with 2ethylhexyl cyanoacetate units as the end-capped blocks and 4,8bis[5-(2-ethylhexyl)thiophen-2-yl]benzo[1,2-b:4,5- $\left.b^{\prime}\right]$-dithiophene as the central core. BHJ OSCs were fabricated using a blend of DCA3T(T-BDT) as the donor and $\mathrm{PC}_{61} \mathrm{BM}$ as the acceptor, with a single layer conventional device architecture of ITO/PEDOT:PSS/DCA3T(T-BDT):PC ${ }_{61} \mathrm{BM} / \mathrm{Ca} / \mathrm{Al}$. The best device exhibited a high PCE of $7.93 \%$ after thermal annealing at a low temperature of $60{ }^{\circ} \mathrm{C}$ for $10 \mathrm{~min}$, with a high $V_{\mathrm{oc}}$ of $0.95 \mathrm{~V}, J_{\mathrm{sc}}$ of $11.86 \mathrm{~mA} \mathrm{~cm}{ }^{-2}$ and $\mathrm{FF}$ of 0.70 . To the best of our knowledge, this is the highest PCE for solution-processed SMOSCs without any solvent additive or interfacial modification treatment found in the conventional devices.

\section{Results and discussion}

\subsection{Synthesis and characterization}

The detailed synthesis and characterization of DCA3T(T-BDT) are given in the experimental section (Scheme 2). The key precursor 7 was synthesized using a $\operatorname{Pd}\left(\mathrm{PPh}_{3}\right)_{4}$-catalyzed Stille coupling reaction between $4^{\prime}, 4^{\prime \prime}$-dioctyl-2,2': $: 5^{\prime}, 2^{\prime \prime}$-trithiophene-5carbaldehyde (5) and 2,6-bis(trimethyltin)-4,8-bis(5-(2-ethylhexyl)thiophen-2yl-)benzo[1,2-b:4,5- $\left.b^{\prime}\right]$ dithiophene (6) in refluxing toluene under argon for 2 days. The target small molecule DCA3T(T-BDT) was obtained through the Knoevenagel condensation of intermediate 7 with 2-ethylhexyl cyanoacetate using triethylamine as the catalyst in anhydrous chloroform $\left(\mathrm{CHCl}_{3}\right)$

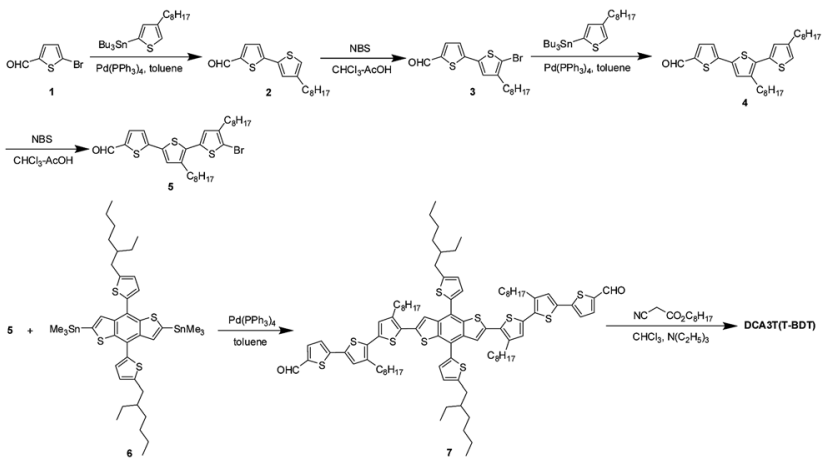

Scheme 2 Synthetic routes towardsDCA3T(T-BDT).

for $40 \mathrm{~h}$. The DCA3T(T-BDT) was fully characterized by NMR spectroscopy, mass spectrometry, electrochemistry, high performance liquid chromatography with UV-detection (HPLCUV), thermogravimetric analysis (TGA) and optical spectroscopy. DCA3T(T-BDT) possesses good solubility at room temperature in common organic solvents, such as toluene, chlorobenzene, $o$-dichlorobenzene, dichloromethane $\left(\mathrm{CH}_{2} \mathrm{Cl}_{2}\right)$ and $\mathrm{CHCl}_{3}$, due to eight solubilizing alkyl side chains.

\subsection{Thermal stability}

TGA and differential scanning calorimetry (DSC) were used to investigate the thermal properties of the small molecule. As shown in Fig. 1, the TGA curve of DCA3T(T-BDT) indicates a good thermal stability with onset decomposition temperature with a $5 \%$ weight loss $\left(T_{\mathrm{d}}\right)$ occurring at $389^{\circ} \mathrm{C}$ under an nitrogen atmosphere. The thermal stability of DCA3T(T-BDT) is high enough to ensure the photovoltaic device fabrication. As shown in Fig. S2, $\uparrow$ the main melting endotherm occurs at $163.7{ }^{\circ} \mathrm{C}$, and upon cooling DCA3T(T-BDT) exhibits a major crystallization exotherm at $133.5{ }^{\circ} \mathrm{C}$, indicating that this small molecule has an obvious tendency to crystallize.

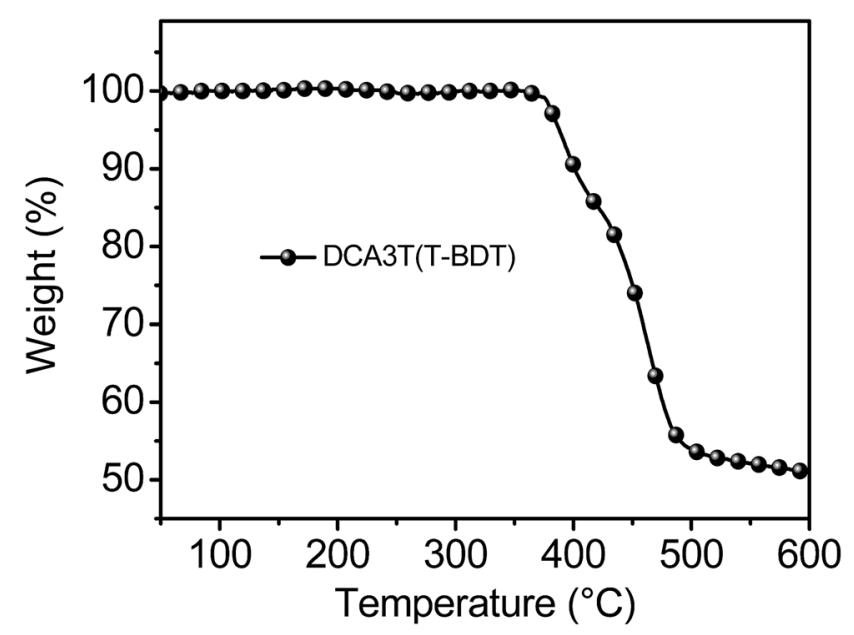

Fig. 1 TGA plot of DCA3T(T-BDT) with a heating rate of $10{ }^{\circ} \mathrm{C} \mathrm{min}^{-1}$ under nitrogen atmosphere. 


\subsection{Optical and electrochemical properties}

UV-vis absorption spectra of DCA3T(T-BDT) were investigated in $\mathrm{CHCl}_{3}$ solution and as a thin film, as shown in Fig. 2a. DCA3T(T-BDT) exhibited a broad absorption range covering 300-700 nm wavelengths in the solid state. In solution, DCA3T(T-BDT) has a maximal absorption $\left(\lambda_{\max }\right)$ peak at $499 \mathrm{~nm}$ corresponding to the intermolecular charge transfer (ICT) interaction between $\mathrm{D}$ and A moieties. ${ }^{\mathbf{4 1 , 4 2}}$ In comparison with its absorption spectrum in solution, the absorption spectrum of DCA3T(T-BDT) as a thin film shows a remarkable red-shifted $\lambda_{\max }$ at $573 \mathrm{~nm}$ with a shoulder peak at $620 \mathrm{~nm}$, indicating that a strong intermolecular $\pi-\pi$ interaction exists in the solid state due to the improved planar construction of the 2D side chains. The optical band gap $\left(E_{\mathrm{g}}^{\text {opt }}\right)$ value of DCA3T(T-BDT) is about $1.80 \mathrm{eV}$, which is deduced from the onset $(690 \mathrm{~nm}$ ) of absorption in the thin film.

Density functional theory (DFT) calculations were employed to investigate the electronic structure and geometry of DCA3T(T-BDT), and the corresponding results are shown in Fig. 3. The electron density of HOMO was mainly delocalized over the central BDT core, and the electron density of the LUMO was concentrated on the 2-ethylhexyl cyanoacetate groups, demonstrating that an electron can transfer from the central BDT group to the end-capped blocks during an electronic excitation process. ${ }^{43}$ From the DFT calculations, the HOMO and LUMO energies of DCA3T(T-BDT) were found to be $-4.98 \mathrm{eV}$ and $-2.82 \mathrm{eV}$, respectively. The electrochemical behavior of DCA3T(T-BDT) was investigated by cyclic voltammetry (CV). As shown in Fig. 2b, the onset oxidation potential for the small molecule was $0.95 \mathrm{~V}$ versus a saturated calomel electrode (SCE).
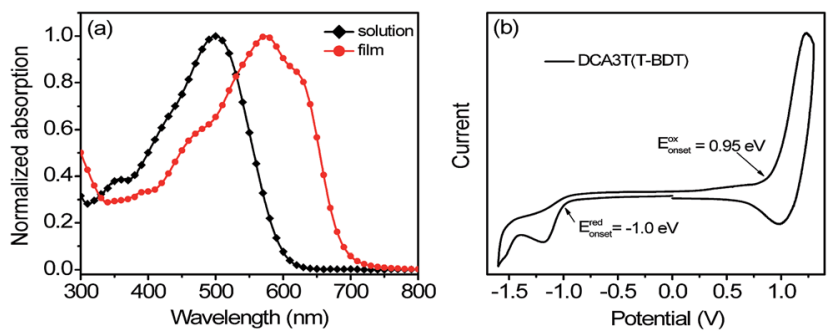

Fig. 2 (a) UV-vis absorption spectra of DCA3T(T-BDT) in $\mathrm{CHCl}_{3}$ solution and as a solid thin film. (b) Cyclic voltammogram of DCA3T(T-BDT) in $0.1 \mathrm{M} \mathrm{Bu}_{4} \mathrm{NPF}_{6}$-acetonitrile solution at a scan rate of $100 \mathrm{mV} \mathrm{s}^{-1}$.
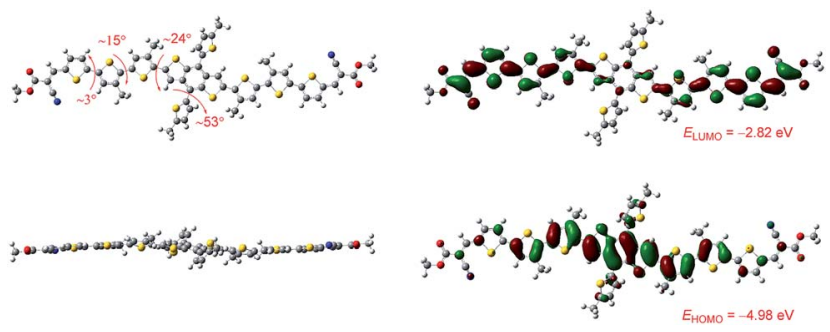

Fig. 3 Optimized molecular geometries and frontier molecular orbitals (isovalue surface $0.02 \mathrm{au}$ ) using DFT evaluated at the B3LYP/6$31 \mathrm{G}(\mathrm{d})$ level of theory.
The corresponding HOMO energy level of DCA3T(T-BDT) was determined to be $-5.37 \mathrm{eV}$. The LUMO energy levels of DCA3T(T-BDT) was estimated to be around $-3.42 \mathrm{eV}$ from the onset reduction potential. This fairly suitable HOMO energy level conveys that a high $V_{\text {oc }}$ of SMOSCs based on DCA3T(T-BDT) blended with $\mathrm{PC}_{61} \mathrm{BM}$ could be expected. ${ }^{31}$ The LUMO energy level difference $(>0.3 \mathrm{eV})$ between the donor and acceptor $\left(\mathrm{PC}_{61} \mathrm{BM}\right)$ is large enough for the separation of the excitons, ${ }^{\mathbf{4 4 - 4 7}}$ which is very useful for increasing the short-circuit current in DCA3T(T-BDT)-based OSCs.

\subsection{Hole mobility}

The high carrier charge mobility is important for effective photovoltaic active layer materials, which would facilitate charge exciton separation from the donor-acceptor interface, carrier transport to the electrodes and reduce recombination. ${ }^{15}$ The carrier charge mobility of DCA3T(T-BDT) was investigated by employing organic field-effect transistors (OFETs) and vertical diodes. DCA3T(T-BDT) exhibited a typical p-type semiconductor behavior (Fig. 4), and the hole mobility was around $0.03 \mathrm{~cm}^{2} \mathrm{~V}^{-1} \mathrm{~s}^{-1}$, calculated according to the transfer characteristic curve. In the vertical direction, the hole mobility was measured by the space-charge limit current (SCLC) ${ }^{48-50}$ model with a typical device structure of ITO/PEDOT:PSS/DCA3T(T-BDT)/Au. SCLC is described by the equation $J_{\mathrm{SCLC}}=(9 / 8)$ $\varepsilon_{0} \varepsilon_{\mathrm{r}} \mu_{\mathrm{h}}\left(\left(V^{2}\right) /\left(L^{3}\right)\right)$, where $J$ stands for current density, $\varepsilon_{0}$ is the permittivity of free space, $\varepsilon_{\mathrm{r}}$ is the relative dielectric constant of the transport medium, $\mu_{\mathrm{h}}$ is the hole mobility, $V$ is the internal potential in the device and $L$ is the thickness of the active layer. The hole mobility of DCA3T(T-BDT) was about $1.2 \times 10^{-4} \mathrm{~cm}^{2}$ $\mathrm{V}^{-1} \mathrm{~s}^{-1}$, calculated using the SCLC model (Fig. S4 $\dagger$ ).

\subsection{Photovoltaic properties}

The BHJ solar cells with a conventional architecture of ITO/ PEDOT:PSS/DCA3T(T-BDT): $\mathrm{PC}_{61} \mathrm{BM} / \mathrm{Ca} / \mathrm{Al}$ using $\mathrm{PC}_{61} \mathrm{BM}$ as the acceptor were fabricated to explore the photovoltaic performance of DCA3T(T-BDT). The detailed device fabrication and measurements are described in the experimental section. First, after thickness optimization, the relative ideal thickness of active layer was around $90 \mathrm{~nm}$ for DCA3T(T-BDT)-based OSCs. The effect of different D/A blend ratios on the performance of SMOSCs based on DCA3T(T-BDT) and $\mathrm{PC}_{61} \mathrm{BM}$ was investigated, and the corresponding results are collected in Table 1 . With an increase of the D/A blend ratio from $1: 1$ to $4: 1, V_{\text {oc }}$ slightly
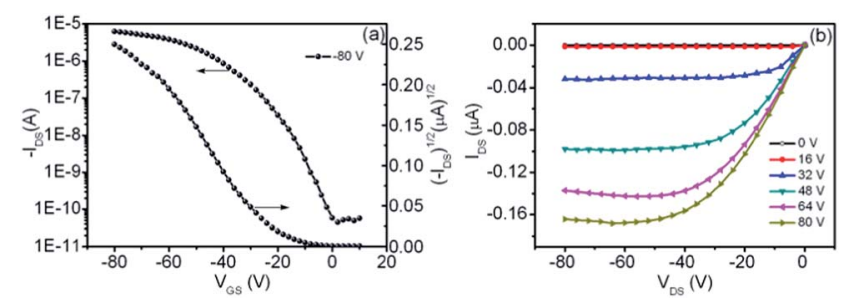

Fig. 4 (a) Transfer and (b) output characteristics ( $\left.V_{D S}=-80 \mathrm{~V}\right)$ for a typical DCA3T(T-BDT)-based OFET device. 
Table 1 The photovoltaic performance of SMOSCs based on DCA3T(T-BDT):PC ${ }_{61} B M$ before and after thermal annealing with different blend ratio

\begin{tabular}{|c|c|c|c|c|c|}
\hline $\mathrm{D}: \mathrm{A}(\mathrm{w} / \mathrm{w})$ & Thermal annealing & $V_{\mathrm{oc}}(\mathrm{V})$ & $J_{\mathrm{sc}}\left(\mathrm{mA} \mathrm{cm}^{-2}\right)$ & $\mathrm{FF}$ & $\mathrm{PCE}_{\max }\left(\mathrm{PCE}_{\mathrm{ave}}{ }^{a}\right)(\%)$ \\
\hline \multirow[t]{2}{*}{$1: 1$} & No & 0.95 & 7.64 & 0.42 & $3.04(2.90)$ \\
\hline & $60{ }^{\circ} \mathrm{C}$ & 0.94 & 9.76 & 0.52 & $4.78(4.61)$ \\
\hline & $60^{\circ} \mathrm{C}$ & 0.95 & 11.33 & 0.67 & $7.25(7.04)$ \\
\hline \multirow[t]{2}{*}{$3: 1$} & No & 0.97 & 11.22 & 0.66 & $7.19(6.98)$ \\
\hline & $40{ }^{\circ} \mathrm{C}$ & 0.96 & 11.27 & 0.68 & $7.36(7.16)$ \\
\hline \multirow[t]{2}{*}{$4: 1$} & No & 0.98 & 10.26 & 0.57 & $5.98(5.79)$ \\
\hline & $60^{\circ} \mathrm{C}$ & 0.95 & 9.16 & 0.70 & $11.11(5.97)$ \\
\hline
\end{tabular}

${ }^{a}$ The average PCE was obtained from over 10 devices.

increased, but $J_{\mathrm{sc}}$ and $\mathrm{FF}$ first increased and then gradually decreased. The optimized device made from the DCA3T(T-BDT) blended with $\mathrm{PC}_{61} \mathrm{BM}(3: 1, \mathrm{w} / \mathrm{w})$ shows the highest PCE of $7.19 \%$, with a $V_{\mathrm{oc}}$ of $0.97 \mathrm{~V}, J_{\mathrm{sc}}$ of $11.22 \mathrm{~mA} \mathrm{~cm} \mathrm{~cm}^{-2}$ and $\mathrm{FF}$ of 0.66 . The high $J_{\text {sc }}$ could be partly ascribed to the better absorption of DCA3T(T-BDT) and the suitable energy matching and larger $V_{\mathrm{oc}}$ agrees with its deeper HOMO energy level $(-5.37 \mathrm{eV})$. The device performance is consistent with the morphologies of the films with different ratio, which are shown in the Fig. 6a-d. The domain in the films is gradually increasing with an increase in the $\mathrm{D}: \mathrm{A}$ ratio, and the domain boundary is reduced. A good interpenetrating network could be formed at the ratio of $3: 1$ (D : A) with relatively low boundary density, which is in favor of the improvement of $J_{\mathrm{sc}}$ and $\mathrm{FF}$.

To further improve the photovoltaic performance of SMOSCs based on DCA3T(T-BDT) and $\mathrm{PC}_{61} \mathrm{BM}$, thermal annealing was employed. The device parameters with different annealing temperatures are summarized in Table 1. The performance of the devices were improved by thermal annealing with higher $J_{\mathrm{sc}}$ and FF compared to the devices as casted. The optimized device based on the DCA3T(T-BDT)/PC ${ }_{61} \mathrm{BM}(3: 1, \mathrm{w} / \mathrm{w})$ blend shows a PCE of $7.93 \%, V_{\text {oc }}$ of $0.95 \mathrm{~V}, J_{\mathrm{sc}}$ of $11.86 \mathrm{~mA} \mathrm{~cm}^{-2}$ and $\mathrm{FF}$ of 0.70 after thermal annealing at only $60^{\circ} \mathrm{C}$ (Fig. 5a). The performance of the devices with different ratios could also be enhanced after annealing, as shown in the Table 1. Therefore, thermal annealing at relatively low temperature is a good method to improve the PCE of the devices and has obvious advantages for
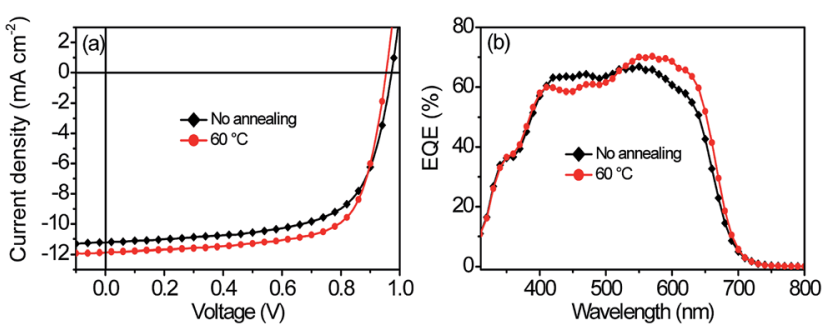

Fig. 5 (a) J-V characteristics and (b) EQE curves of the devices based on DCA3T(T-BDT): $\mathrm{PC}_{61} \mathrm{BM}$ before and after thermal annealing at $60{ }^{\circ} \mathrm{C}$ with a blend ratio of $3: 1$. large scale production. It is worth noting that all the devices exhibited high $V_{\text {oc }}(0.94-0.98 \mathrm{~V})$, which were almost insensitive to the annealed temperature and the $\mathrm{D} / \mathrm{A}$ weight ratios. The $J-V$ curves of the devices with different $\mathrm{D} / \mathrm{A}$ blend ratios under the illumination of AM 1.5G $\left(100 \mathrm{~mW} \mathrm{~cm}^{-2}\right)$ are shown in Fig. S3. $\dagger$ As a result, DCA3T(T-BDT) would be a promising donor material for high efficiency SMOSCs.

The EQE curve of the optimized device covered a broad wavelength range of $310-700 \mathrm{~nm}$ with a maximum value of $70 \%$ at $569 \mathrm{~nm}$ as shown in Fig. 5b. After thermal annealing at $60^{\circ} \mathrm{C}$, the photoresponse is enhanced at the long wavelength region, which may be the contribution of improvement of the crystallization. $J_{\mathrm{sc}}$ calculated from the EQE curve is $11.34 \mathrm{~mA} \mathrm{~cm}{ }^{-2}$, which is consistent with the $J_{\mathrm{sc}}$ value obtained from the $J-V$ curve.

\subsection{Morphology and structural (X-ray) characterization}

The enhanced device performance by the thermal annealing process at low temperature could be partially attributed to a better interpenetrating network. ${ }^{27}$ The morphologies of the films with the DCA3T(T-BDT): $\mathrm{PC}_{61} \mathrm{BM} \quad(3: 1, \mathrm{w} / \mathrm{w})$ blend annealing at different temperatures are given in Fig. S5. $\dagger$ The films after annealing show a lower root mean square compared to the pristine ones. Upon increasing the annealing temperature from 40 to $80^{\circ} \mathrm{C}$, the domain boundary intensity gradually reduced, which would decrease the trap state density existing in the boundary and therefore reduce the recombination current and improve the transport and collection of the carrier charge. ${ }^{51}$ This may also be an important reason for the improvement of $J_{\mathrm{sc}}$ and $\mathrm{FF}$ in this work. The morphologies of films with different $\mathrm{D}$ : A ratio after annealing at $60{ }^{\circ} \mathrm{C}$ are given in Fig. 6e-h. All films show a lower boundary intensity compared to their films as casted. Therefore, it is believed that thermal annealing at relatively low temperature may be an effective method to enhance the performance of devices by reducing the boundary intensity.

To further understand the performance difference of DCA3T(T-BDT)-based SMOSCs before and after thermal annealing at $60{ }^{\circ} \mathrm{C}$, the crystallinity of the DCA3T(T-BDT) 

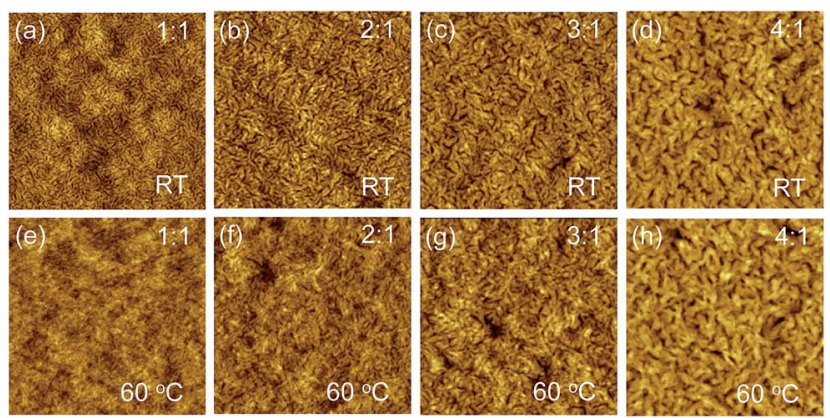

Fig. 6 Tapping mode AFM height images $(4 \mu \mathrm{m} \times 4 \mu \mathrm{m})$ of DCA3T(T$\mathrm{BDT}$ ): $\mathrm{PC}_{61} \mathrm{BM}$ blend films with different $\mathrm{D} / \mathrm{A}$ ratios before (top: $\mathrm{a}-\mathrm{d}$ ) and after (bottom: e-h) thermal annealing at $60^{\circ} \mathrm{C}$.

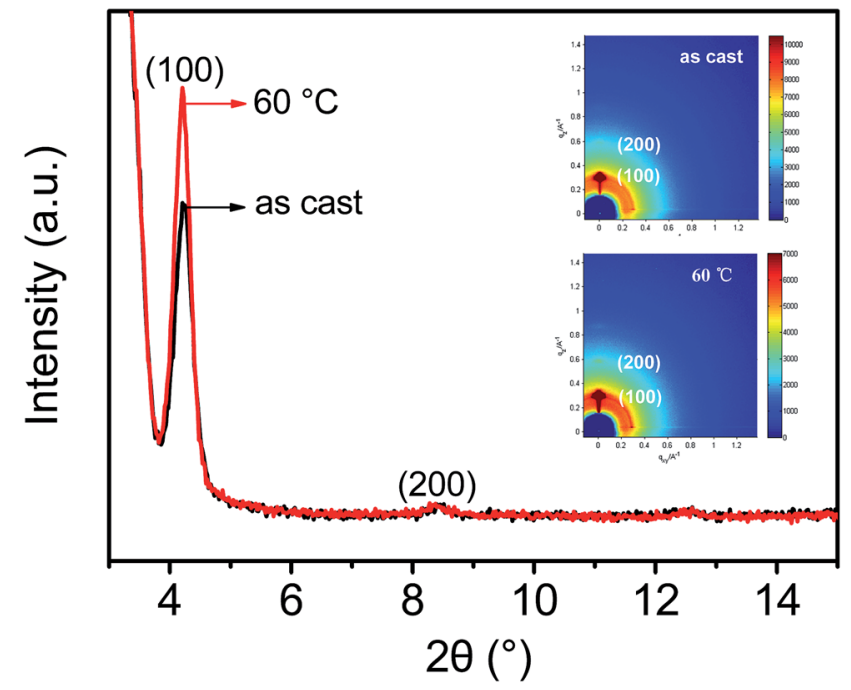

Fig. 7 XRD patterns of DCA3T(T-BDT) film spin-coated from $\mathrm{CHCl}_{3}$ solution before and after thermal annealing at $60^{\circ} \mathrm{C}$. The insets are the corresponding 2D GIWAXS images.

blend films was investigated by X-ray diffraction (XRD) and two-dimensional (2D) grazing incidence wide-angle X-ray scattering (GIWAXS), respectively. As shown in Fig. 7, the diffraction peak of the annealing film remained at the same position, and the intensity was obviously enhanced. Both of the films show an evident diffraction peak (100) at $2 \theta=4.2^{\circ}$, corresponding to a $d_{100^{-}}$-spacing value of $21.0 \AA$. The secondorder diffraction peak (200) at $2 \theta=8.4^{\circ}$, corresponding to a $d_{200}$-spacing value of $10.5 \AA$ was also clearly observed, indicating the high crystallinity of DCA3T(T-BDT) in the solid thin film. The stronger diffraction peak of the annealing film compared to the pristine one reveals that the low temperature annealing would improve the ordering in the donor phase. ${ }^{52,53}$ The 2D GIWAXS patterns also indicate a well-ordered crystal structure throughout the corresponding thin film. The high crystallinity could increase the carrier mobility, which would be benefit for the transport and collection of the carrier, ${ }^{54}$ thus leading to a higher $J_{\mathrm{sc}}$ and FF.

\section{Conclusion}

In conclusion, a new low band gap and 2D-conjugated organic small molecule, DCA3T(T-BDT), was designed and synthesized for solution-processed organic solar cells. DCA3T(T-BDT) exhibited good solubility, thermal stability, crystallinity and a deeper HOMO energy level of $-5.37 \mathrm{eV}$. High efficiency small molecule organic solar cell with a power conversion efficiency of $7.93 \%$, a high $V_{\text {oc }}$ of $0.95 \mathrm{~V}, J_{\mathrm{sc}}$ of $11.86 \mathrm{~mA} \mathrm{~cm}^{-2}$ and $\mathrm{FF}$ of 0.70 was obtained by thermal annealing process at only $60{ }^{\circ} \mathrm{C}$. Hence, this encouraging result reveals a prospective strategy for a new 2D heterocyclic core in constructing donor-acceptor type small molecules for high performance organic solar cells.

\section{Experimental section}

\subsection{Materials, instruments and characterization}

All starting materials and reagents were purchased from commercial sources and used without further purification, unless otherwise mentioned. Toluene was distilled over sodium in the presence of benzophenone to remove water. $\mathrm{CHCl}_{3}$ and $\mathrm{CH}_{2} \mathrm{Cl}_{2}$ were distilled over calcium hydride $\left(\mathrm{CaH}_{2}\right)$.

${ }^{1} \mathrm{H}$ and ${ }^{13} \mathrm{C}$ NMR spectra were obtained on a Bruker Advance III 600 spectrometer with tetramethylsilane (TMS, $\delta=0 \mathrm{ppm}$ ) as an internal standard. UV-vis absorption spectra were obtained on a Hitachi U-4100 spectrophotometer. High resolution mass spectra were recorded under APCI mode on a Bruker Maxis UHR TOF spectrometer. TGA and DSC were carried on SDT Q600 simultaneous DSC-TGA instrument and Perkin Elmer diamond differential scanning calorimeter, respectively. Cyclic voltammetry (CV) measurements were taken on a CHI660D electrochemical workstation. Moreover, $\mathrm{CV}$ experiments were carried out at room temperature with a conventional three-electrode system using a platinum wire as the counter electrode, a saturated calomel electrode (SCE) as the reference electrode, and a glassy carbon electrode as the working electrode. A solution of tetrabutylammonium phosphorus hexafluoride $\left(\mathrm{Bu}_{4} \mathrm{NPF}_{6}\right.$, $0.1 \mathrm{M}$ ) in acetonitrile was used as the supporting electrolyte, at a scan rate of $100 \mathrm{mV} \mathrm{s}^{-1}$. Ferrocene/ferrocenium $\left(\mathrm{Fc} / \mathrm{Fc}^{+}\right)$was used as the internal standard (the energy level of $\mathrm{Fc} / \mathrm{Fc}^{+}$is $-4.8 \mathrm{eV}$ under vacuum) and the formal potential of $\mathrm{Fc} / \mathrm{Fc}^{+}$was measured as $0.38 \mathrm{~V} v$ s. SCE. HPLC-UV was carried on a Waters 1525 high performance liquid chromatography with UV detection.

Density functional theory (DFT) calculations were performed using the Gaussian 09 program suite at the B3LYP/6-31G(d) level to investigate the electronic structure of the molecule in the gas phase..$^{5-58}$ All the alkyl side chains were replaced with methyl groups to reduce the computational cost. The optimized molecular structure was confirmed to be in a stable local minimum of the ground state potential energy surface by computing the vibrational frequencies at the same level of theory.

OFET was fabricated using n-type heavily doped $\mathrm{Si}$ as the gate with a $300 \mathrm{~nm}$ thermally oxidized $\mathrm{SiO}_{2}$ layer as the gate dielectric (the capacitance was $10 \mathrm{nF} \mathrm{cm} \mathrm{cm}^{-2}$ ). The film was prepared by spin-coating the solution $\left(6 \mathrm{mg} \mathrm{mL}^{-1}\right.$ in $\left.\mathrm{CHCl}_{3}\right)$ on 
octadecyltrichlorosilane (OTS)-treated $\mathrm{SiO}_{2} / \mathrm{Si}$. The Au source and drain electrodes were deposited on the film through a shadow mask with a length of $31 \mu \mathrm{m}$ and a width of $273 \mu \mathrm{m}$. Measurements were performed using a 4200 semiconductor parameter analyzer in air.

\subsection{Fabrication of DCA3T(T-BDT)-based organic solar cells}

SMOSCs were fabricated with a structure of ITO/PEDOT :PSS/ DCA3T(T-BDT): $\mathrm{PC}_{61} \mathrm{BM} / \mathrm{Ca} / \mathrm{Al}$ using a conventional solution spin-coating process. The ITO-coated glass substrates were cleaned by ultrasonic treatment in detergent, deionized water, acetone and isopropyl alcohol under ultrasonication for $20 \mathrm{~min}$. A thin layer of PEDOT:PSS was spin-coated (4000 rpm, ca. $40 \mathrm{~nm}$ thick) onto the ITO surface. After being baked at $150{ }^{\circ} \mathrm{C}$ for 20 $\min$, the substrates were transferred into a glove box. Subsequently, the active layer was spin-coated from different ratio blends of DCA3T(T-BDT) and $\mathrm{PC}_{61} \mathrm{BM}$ in $\mathrm{CHCl}_{3}$ solution at 1500 rpm for $25 \mathrm{~s}$ on the ITO/PEDOT:PSS substrate. Finally, a $10 \mathrm{~nm}$ Ca layer and $100 \mathrm{~nm}$ Al layer were successively deposited onto the active layer under high vacuum by a shadow mask to define the area of $0.1 \mathrm{~cm}^{2}\left(<3 \times 10^{-4} \mathrm{~Pa}\right)$. The thermal annealing was carried out by placing the completed devices on a digitally controlled hotplate at different temperatures, in an argon-filled glove box.

\subsection{Measurement and characterization of devices}

The structure of the films was analyzed using grazing incidence X-ray diffraction (GIXRD, Bruker D8 ADVANCE). Surface morphological characterization of the films were carried out by a tapping-mode atomic force microscope (AFM, Agilent 5400). Current density-voltage $(J-V)$ characteristics of the devices were analyzed with a Keithley 2420 source measurement unit under simulated $100 \mathrm{~mW} \mathrm{~cm}^{-2}$ (AM 1.5G) irradiation from a Newport solar simulator. Light intensity was calibrated with a standard silicon solar cell. Further, the external quantum efficiencies (EQE) of solar cells were analyzed using a certified Newport incident photon conversion efficiency (IPCE) measurement system.

\subsection{Synthesis}

All coupling reactions were conducted under purified argon and monitored by Merck silica-gel thin-layer chromatography (TLC). 2-(Tributylstannyl)-4-octylthiophene and 2,6-bis(trimethyltin)4,8-bis(5-(2-ethylhexyl)thiophen-2yl-)benzo[1,2-b:4,5- $\left.b^{\prime}\right]$ dithiophene (6) were synthesized according to the literature procedures. ${ }^{59,60}$

4'-Octyl-2,2'-bithiophene-5-carbaldehyde (2). In a $100 \mathrm{~mL}$ flame-dried flask, 2-(tributylstannyl)-4-octylthiophene $(8.90 \mathrm{~g}$, $18.32 \mathrm{mmol}$ ), 5-bromo-2-thiophene-carbaldehyde (3.18 g, 16.5 $\mathrm{mmol})$ and $\mathrm{Pd}\left(\mathrm{PPh}_{3}\right)_{4}(0.76 \mathrm{~g}, 0.66 \mathrm{mmol})$ were dissolved in anhydrous degassed toluene $(60 \mathrm{~mL})$. The mixture was slowly heated up to $110{ }^{\circ} \mathrm{C}$ and stirred at this temperature overnight under an argon atmosphere. After cooling down to the room temperature, the mixture was poured into water and extracted three times with $\mathrm{CH}_{2} \mathrm{Cl}_{2}$. The combined organic phase was dried over anhydrous $\mathrm{Na}_{2} \mathrm{SO}_{4}$ and concentrated under vacuum.
The crude residue was purified by column chromatography on silica gel using petroleum $/ \mathrm{CH}_{2} \mathrm{Cl}_{2}$ as eluent. After removing the solvents, a light yellow solid compound 2 (2.86 g, 57\%) was obtained.

${ }^{1} \mathrm{H}$ NMR $\left(600 \mathrm{MHz}, \mathrm{CDCl}_{3}\right), \delta(\mathrm{ppm}): 9.85(\mathrm{~s}, 1 \mathrm{H}), 7.65(\mathrm{~d}, 1 \mathrm{H})$, $7.21(\mathrm{~d}, 1 \mathrm{H}), 7.19(\mathrm{~d}, 1 \mathrm{H}), 6.95(\mathrm{~d}, 1 \mathrm{H}), 2.60(\mathrm{t}, 2 \mathrm{H}), 1.63(\mathrm{~m}, 2 \mathrm{H})$, $1.35-1.25(\mathrm{~m}, 10 \mathrm{H}), 0.88(\mathrm{t}, 3 \mathrm{H}) .{ }^{13} \mathrm{C}$ NMR $\left(150 \mathrm{MHz}, \mathrm{CDCl}_{3}\right), \delta$ (ppm): 182.53, 147.68, 144.79, 141.45, 137.35, 135.63, 127.46, 123.91, 121.93, 31.87, 30.40, 30.38, 29.39, 29.27, 29.25, 22.67, 14.11.

$5^{\prime}$-Bromo-4'-octyl-2,2'-bithiophene-5-carbaldehyde (3). In a $250 \mathrm{~mL}$ flask, compound $2(2.45 \mathrm{~g}, 8.0 \mathrm{mmol})$ was dissolved in a mixture of $\mathrm{CHCl}_{3}(60 \mathrm{~mL})$ and acetic acid $(60 \mathrm{~mL})$. Under argon atmosphere and dark against light, $N$-bromosuccinimide (NBS) $(1.43 \mathrm{~g}, 8.0 \mathrm{mmol})$ was added to the solution in small portions and the reaction mixture was stirred for $8 \mathrm{~h}$ at room temperature. The mixture was diluted with water and extracted with $\mathrm{CH}_{2} \mathrm{Cl}_{2}$ three times. The combined organic phase was dried over anhydrous $\mathrm{Na}_{2} \mathrm{SO}_{4}$ and the solvent was removed by rotary evaporator. The crude product was purified by column chromatography on silica gel using petroleum/ $\mathrm{CH}_{2} \mathrm{Cl}_{2}$ as eluent. After evaporating the solvent under vacuum, compound 3 $(2.20 \mathrm{~g}, 72 \%)$ was obtained as a yellow solid.

${ }^{1} \mathrm{H}$ NMR $\left(600 \mathrm{MHz}, \mathrm{CDCl}_{3}\right), \delta(\mathrm{ppm}): 9.84(\mathrm{~s}, 1 \mathrm{H}), 7.62(\mathrm{~d}, 1 \mathrm{H})$, $7.13(\mathrm{~d}, 1 \mathrm{H}), 7.02(\mathrm{~s}, 1 \mathrm{H}), 2.53(\mathrm{t}, 2 \mathrm{H}), 1.58(\mathrm{~m}, 2 \mathrm{H}), 1.33-1.25(\mathrm{~m}$, $10 \mathrm{H}), 0.88(\mathrm{t}, 3 \mathrm{H}) .{ }^{13} \mathrm{C}$ NMR (150 MHz, $\left.\mathrm{CDCl}_{3}\right), \delta(\mathrm{ppm}): 182.37$, 146.25, 143.66, 141.72, 137.22, 135.39, 126.75, 124.03, 110.96, $31.86,29.60,29.52,29.34,29.22,29.20,22.67,14.12$.

$4^{\prime}, \mathbf{4}^{\prime \prime}$-Dioctyl-2,2':5', $\mathbf{2}^{\prime \prime}$-trithiophene-5-carbaldehyde (4). In a $100 \mathrm{~mL}$ flame-dried flask, compound $3(2.18 \mathrm{~g}, 5.65 \mathrm{mmol}), 2-$ (tributylstannyl)-4-octylthiophene (3.29 g, $6.78 \mathrm{mmol})$ and $\mathrm{Pd}\left(\mathrm{PPh}_{3}\right)_{4}(0.19 \mathrm{~g}, 0.17 \mathrm{mmol})$ were dissolved in anhydrous degassed toluene $(45 \mathrm{~mL})$. The mixture was heated at $110{ }^{\circ} \mathrm{C}$ overnight under an argon atmosphere. After cooling down to the room temperature, the mixture was poured into water and extracted with $\mathrm{CH}_{2} \mathrm{Cl}_{2}$ three times. The combined organic phase was dried over anhydrous $\mathrm{Na}_{2} \mathrm{SO}_{4}$ and concentrated under vacuum. The crude residue was purified by column chromatography on silica gel using petroleum/ $\mathrm{CH}_{2} \mathrm{Cl}_{2}$ as eluent to obtain compound $4(1.69 \mathrm{~g}, 60 \%)$ as a red solid.

${ }^{1} \mathrm{H} \mathrm{NMR}\left(600 \mathrm{MHz}, \mathrm{CDCl}_{3}\right), \delta(\mathrm{ppm}): 9.84(\mathrm{~s}, 1 \mathrm{H}), 7.64(\mathrm{~d}, 1 \mathrm{H})$, $7.19(\mathrm{~d}, 1 \mathrm{H}), 7.17(\mathrm{~s}, 1 \mathrm{H}), 6.99(\mathrm{~d}, 1 \mathrm{H}), 6.93(\mathrm{~s}, 1 \mathrm{H}), 2.73(\mathrm{t}, 2 \mathrm{H})$, $2.60(\mathrm{t}, 2 \mathrm{H}), 1.67-1.61(\mathrm{~m}, 4 \mathrm{H}), 1.40-1.27(\mathrm{~m}, 20 \mathrm{H}), 0.88(\mathrm{~m}, 6 \mathrm{H})$. ${ }^{13} \mathrm{C}$ NMR (150 MHz, $\left.\mathrm{CDCl}_{3}\right), \delta(\mathrm{ppm}): 182.39,147.15,143.87$, 141.40, 140.51, 137.40, 134.84, 133.28, 133.11, 129.00, 127.75, $123.85,120.79,31.90,31.88,30.50,30.46,30.43,29.52,29.44$, 29.38, 29.34, 29.30, 29.28, 29.26, 22.68, 14.12 .

$5^{\prime \prime}$-Bromo-4', $\mathbf{4}^{\prime \prime}$-dioctyl-2,2': $\mathbf{5}^{\prime}, \mathbf{2}^{\prime \prime}$-trithiophene-5-carbaldehyde (5). In a $250 \mathrm{~mL}$ flask, compound $4(1.67 \mathrm{~g}, 3.33 \mathrm{mmol})$ was dissolved in a mixture of $\mathrm{CHCl}_{3}(50 \mathrm{~mL})$ and acetic acid $(50 \mathrm{~mL})$. Under argon atmosphere and dark against light, NBS (0.62 g, $3.50 \mathrm{mmol}$ ) was added to the solution in small portions, and the reaction mixture was stirred for $6 \mathrm{~h}$ at room temperature. The mixture was diluted with water and extracted with $\mathrm{CH}_{2} \mathrm{Cl}_{2}$ three times. The organic phase was dried over $\mathrm{Na}_{2} \mathrm{SO}_{4}$ and the solvent was removed under vacuum. The crude product was purified by 
column chromatography on silica gel with petroleum/ $\mathrm{CH}_{2} \mathrm{Cl}_{2}$ as eluent to obtain compound $5(1.59 \mathrm{~g}, 82 \%)$ as an orange solid.

${ }^{1} \mathrm{H}$ NMR $\left(600 \mathrm{MHz}, \mathrm{CDCl}_{3}\right), \delta(\mathrm{ppm}): 9.86(\mathrm{~s}, 1 \mathrm{H}), 7.66(\mathrm{~d}, 1 \mathrm{H})$, $7.21(\mathrm{~d}, 1 \mathrm{H}), 7.16(\mathrm{~s}, 1 \mathrm{H}), 6.85(\mathrm{~s}, 1 \mathrm{H}), 2.70(\mathrm{t}, 2 \mathrm{H}), 2.57(\mathrm{t}, 2 \mathrm{H})$, 1.66-1.58 (m, 4H), 1.38-1.25 (m, 20H), $0.89(\mathrm{~m}, 6 \mathrm{H}) .{ }^{13} \mathrm{C} \mathrm{NMR}$ $\left(150 \mathrm{MHz}, \mathrm{CDCl}_{3}\right), \delta(\mathrm{ppm}): 182.39,146.80,142.69,141.63$, 141.03, 137.34, 134.65, 133.63, 132.12, 128.91, 127.23, 124.04, 109.57, 31.89, 31.87, 30.50, 29.67, 29.53, 29.47, 29.38, 29.37, 29.28, 29.25, 22.68, 14.13. MS (UHR-TOF) $\mathrm{m} / z\left[\mathrm{M}^{+}\right]=578.1342$ (calcd for $\mathrm{C}_{29} \mathrm{H}_{39} \mathrm{BrOS}_{3}, 578.1346$ ).

Compound (7). In a $100 \mathrm{~mL}$ well flame-dried flask, compound 5 (1.52 g, $2.62 \mathrm{mmol})$ and compound 6 (1.04 g, 1.15 $\mathrm{mmol}$ ) were dissolved in anhydrous toluene $(50 \mathrm{~mL})$. After the solution was degassed with argon three times, $\operatorname{Pd}\left(\mathrm{PPh}_{3}\right)_{4}(0.15 \mathrm{~g}$, $0.13 \mathrm{mmol}$ ) was added. The reaction mixture was heated at 110 ${ }^{\circ} \mathrm{C}$ for $2 \mathrm{~d}$ under an argon atmosphere. After cooling down to room temperature, the mixture was poured into water and extracted with $\mathrm{CH}_{2} \mathrm{Cl}_{2}$ three times. The combined organic phase was dried over $\mathrm{Na}_{2} \mathrm{SO}_{4}$ and concentrated under vacuum. The crude residue was purified by column chromatography on silica gel using petroleum $/ \mathrm{CH}_{2} \mathrm{Cl}_{2}$ as eluent to obtain compound 7 $(1.18 \mathrm{~g}, 65 \%)$ as a red solid.

${ }^{1} \mathrm{H}$ NMR (600 MHz, $\left.\mathrm{CDCl}_{3}\right), \delta(\mathrm{ppm}): 9.86(\mathrm{~s}, 2 \mathrm{H}), 7.68(\mathrm{~s}, 2 \mathrm{H})$, $7.66(\mathrm{~d}, 2 \mathrm{H}), 7.35$ (d, 2H), $7.21(\mathrm{~d}, 2 \mathrm{H}), 7.19(\mathrm{~s}, 2 \mathrm{H}), 7.02(\mathrm{~s}, 2 \mathrm{H})$, $6.92(\mathrm{~d}, 2 \mathrm{H}), 2.88(\mathrm{~d}, 4 \mathrm{H}), 2.83(\mathrm{t}, 4 \mathrm{H}), 2.78(\mathrm{t}, 4 \mathrm{H}), 1.72-1.65(\mathrm{~m}$, 10H), 1.43-1.26 (m, 56H), 0.97-0.85 (m, 24H). ${ }^{13} \mathrm{C}$ NMR (150 $\left.\mathrm{MHz}, \mathrm{CDCl}_{3}\right), \delta$ (ppm): 182.40, 146.94, 145.95, 141.55, 141.53, 140.99, 139.04, 137.38, 136.92, 136.67, 134.46, 133.48, 132.56, 131.53, 129.42, 129.13, 127.78, 125.46, 123.99, 123.36, 121.70, $41.50,34.31,32.54,31.93,31.87,30.61,30.40,29.61,29.55$, $29.49,29.47,29.43,29.41,29.35,29.25,28.94,25.73,23.05$, $22.71,22.67,14.18,14.12,14.11,10.92$. MS (UHR-TOF): calcd for $\mathrm{C}_{92} \mathrm{H}_{118} \mathrm{O}_{2} \mathrm{~S}_{10}[\mathrm{M}]^{+}, 1574.6339$; found, 1574.6298 .

Compound DCA3T(T-BDT). Under protection of argon, to a stirred solution of $\mathrm{CHCl}_{3}(35 \mathrm{~mL})$, triethylamine $(0.1 \mathrm{~mL})$ and compound 7 ( $0.55 \mathrm{~g}, 0.35 \mathrm{mmol})$ was added 2-ethylhexyl cyanoacetate $(0.8 \mathrm{~mL}, 3.8 \mathrm{mmol})$ using a syringe at room temperature. The mixture was stirred for 40 hours under argon. The mixture was diluted with water $(45 \mathrm{~mL})$ and extracted with $\mathrm{CHCl}_{3}$ three times. The organic phase was dried over $\mathrm{Na}_{2} \mathrm{SO}_{4}$ and the solvent was removed under vacuum. The crude product was purified by column chromatography on silica gel using petroleum $/ \mathrm{CH}_{2} \mathrm{Cl}_{2}$ as eluent to obtain DCA3T(T-BDT) $(0.51 \mathrm{~g}$, $75 \%)$ as a black solid.

${ }^{1} \mathrm{H}$ NMR $\left(600 \mathrm{MHz}, \mathrm{CDCl}_{3}\right), \delta(\mathrm{ppm}): 8.24(\mathrm{~s}, 2 \mathrm{H}), 7.68(\mathrm{~s}, 2 \mathrm{H})$, $7.65(\mathrm{~d}, 2 \mathrm{H}), 7.36(\mathrm{~d}, 2 \mathrm{H}), 7.24(\mathrm{~s}, 2 \mathrm{H}), 7.21(\mathrm{~d}, 2 \mathrm{H}), 7.04(\mathrm{~s}, 2 \mathrm{H})$, $6.92(\mathrm{~d}, 2 \mathrm{H}), 4.22(\mathrm{~m}, 4 \mathrm{H}), 2.88(\mathrm{~d}, 4 \mathrm{H}), 2.84(\mathrm{t}, 4 \mathrm{H}), 2.78(\mathrm{t}, 4 \mathrm{H})$, $1.70(\mathrm{~m}, 12 \mathrm{H}), 1.48-1.26(\mathrm{~m}, 72 \mathrm{H}), 0.97-0.86(\mathrm{~m}, 36 \mathrm{H}) .{ }^{13} \mathrm{C}$ NMR $\left(150 \mathrm{MHz}, \mathrm{CDCl}_{3}\right), \delta(\mathrm{ppm}): 163.21,147.28,146.09,145.96$, 141.56, 141.21, 139.28, 139.04, 136.92, 136.90, 136.65, 134.42, 134.19, 133.17, 133.04, 131.66, 129.59, 129.48, 127.79, 125.47, 124.18, 123.37, 121.73, 116.02, 97.55, 68.82, 41.19, 38.79, 34.30, $32.54,31.93,31.87,30.59,30.40,30.32,29.61,29.55,29.51$, $29.47,29.41,29.35,29.26,28.94,28.93,25.72,23.76,23.05$, $22.95,22.71,22.68,14.18,14.13,14.06,11.02,10.92$. MS (UHRTOF): calcd for $\mathrm{C}_{114} \mathrm{H}_{152} \mathrm{~N}_{2} \mathrm{O}_{4} \mathrm{~S}_{10}[\mathrm{M}]^{+}, 1932.8959$; found, 1932.8962.

\section{Acknowledgements}

This work was supported by the Ministry of Science and Technology of China (2014CB643501, 2010DFA52310), the National Natural Science Foundation of China (21274161, 21202181, 51173199 and 61107090), Chinese Academy of Sciences (KGCX2-YW-399+9-2), and Qingdao Municipal Science and Technology Program (11-2-4-22-hz).

\section{Notes and references}

1 G. Yu, J. Gao, J. C. Hummelen, F. Wudl and A. J. Heeger, Science, 1995, 270, 1789.

2 Z. B. Henson, K. Müllen and G. C. Bazan, Nat. Chem., 2012, 4, 699.

3 B. C. Thompson and J. M. Frechet, Angew. Chem., Int. Ed., 2008, 47, 58.

4 J. Chen and Y. Cao, Acc. Chem. Res., 2009, 42, 1709.

5 K. Müllen and T. M. Swager, Acc. Chem. Res., 2008, 41, 1085. 6 J. Hou, H. Y. Chen, S. Zhang, R. I. Chen, Y. Yang, Y. Wu and G. Li, J. Am. Chem. Soc., 2009, 131, 15586.

7 S. Günes, H. Neugebaue and N. S. Sariciftci, Chem. Rev., 2007, 107, 1324.

8 X. Zhang, Z. Lu, L. Ye, C. Zhan, J. Hou, S. Zhang, B. Jiang, Y. Zhao, J. Huang, S. Zhang, Y. Liu, Q. Shi, Y. Liu and J. Yao, Adv. Mater., 2013, 25, 5791.

9 X. Guo, M. Baumgarten and K. Müllen, Prog. Polym. Sci., 2013, 38, 1832.

10 Z. He, C. Zhong, S. Su, M. Xu, H. Wu and Y. Cao, Nat. Photon., 2012, 6, 591.

11 D. H. Wang, A. K. K. Kyaw, V. Gupta, G. C. Bazan and A. J. Heeger, Adv. Energy Mater., 2013, 3, 1161.

12 (a) J. Zhou, Y. Zuo, X. Wan, G. Long, Q. Zhang, W. Ni, Y. Liu, Z. Li, G. He, C. Li, B. Kan, M. Li and Y. Chen, J. Am. Chem. Soc., 2013, 135, 8484; (b) Y. Liu, C. Chen, Z. Hong, J. Gao, Y. M. Yang, H. Zhou, L. Dou, G. Li and Y. Yang, Sci. Rep., 2013, 3, 3356.

13 Y. Sun, G. C. Welch, W. L. Leong, C. J. Takacs, G. C. Bazan and A. J. Heeger, Nat. Mater., 2011, 11, 44.

14 Y. Liu, Y. M. Yang, C. C. Chen, Q. Chen, L. Dou, Z. Hong, G. Li and Y. Yang, Adv. Mater., 2013, 25, 4657.

15 Y. Lin, L. Ma, Y. Li, Y. Liu, D. Zhu and X. Zhan, Adv. Energy Mater., 2013, 3, 1166.

16 A. B. Tamayo, X. D. Dang, B. Walker, J. Seo, T. Kent and T. Q. Nguyen, Appl. Phys. Lett., 2009, 94, 103301.

17 Y. Chen, X. Wan and G. Long, Acc. Chem. Res., 2013, 46, 2645. $18 \mathrm{~N}$. M. Kronenberg, M. Deppisch, F. Wurthner, H. W. Lademann, K. Deing and K. Meerholz, Chem. Commun., 2008, 6489.

19 S. Loser, C. J. Bruns, H. Miyauchi, R. P. Ortiz, A. Facchetti, S. I. Stupp and T. J. Marks, J. Am. Chem. Soc., 2011, 133, 8142. 20 J. Zhou, X. Wan, Y. Liu, Y. Zuo, Z. Li, G. He, G. Long, W. Ni, C. Li, X. Su and Y. Chen, J. Am. Chem. Soc., 2012, 134, 16345. 21 J. Liu, Y. Sun, P. Moonsin, M. Kuik, C. M. Proctor, J. Lin, B. B. Hsu, V. Promarak, A. J. Heeger and T. Q. Nguyen, Adv. Mater., 2013, 25, 5898. 
22 T. Bura, N. Leclerc, R. Bechara, P. Lévêque, T. Heiser and R. Ziessel, Adv. Energy Mater., 2013, 3, 1118.

23 H. C. Chen, Y. H. Chen, C. C. Liu, Y. C. Chien, S. W. Chou and P. T. Chou, Chem. Mater., 2012, 24, 4766.

24 C. Cabanetos, A. E. Labban, J. A. Bartelt, J. D. Douglas, W. R. Mateker, J. M. Frechet, M. D. McGehee and P. M. Beaujuge, J. Am. Chem. Soc., 2013, 135, 4656.

25 N. Zhou, X. Guo, R. P. Ortiz, S. Li, S. Zhang, R. P. Chang, A. Facchetti and T. J. Marks, Adv. Mater., 2012, 24, 2242.

26 B. Walker, C. Kim and T. Q. Nguyen, Chem. Mater., 2011, 23, 470.

27 A. Mishra and P. Bauerle, Angew. Chem., Int. Ed., 2012, 51, 2020.

28 J. Min, Z. G. Zhang, S. Zhang and Y. Li, Chem. Mater., 2012, 24, 3247.

29 L. Dou, J. Gao, E. Richard, J. You, C. C. Chen, K. C. Cha, Y. He, G. Li and Y. Yang, J. Am. Chem. Soc., 2012, 134, 10071.

30 W. Li, W. S. Roelofs, M. M. Wienk and R. A. Janssen, J. Am. Chem. Soc., 2012, 134, 13787.

31 L. Huo, J. Hou, S. Zhang, H. Y. Chen and Y. Yang, Angew. Chem., Int. Ed., 2010, 49, 1500.

32 Y. Huang, X. Guo, F. Liu, L. Huo, Y. Chen, T. P. Russell, C. C. Han, Y. Li and J. Hou, Adv. Mater., 2012, 24, 3383.

33 D. Lee, E. Hubijar, G. J. D. Kalaw and J. P. Ferraris, Chem. Mater., 2012, 24, 2534.

34 Y. Li, Acc. Chem. Res., 2012, 45, 723.

35 M. Zhang, Y. Gu, X. Guo, F. Liu, S. Zhang, L. Huo, T. P. Russell and J. Hou, Adv. Mater., 2013, 25, 4944.

36 D. Patra, T. Y. Huang, C. C. Chiang, R. O. V. Maturana, C. W. Pao, K. C. Ho, K. H. Wei and C. W. Chu, ACS Appl. Mater. Interfaces, 2013, 5, 9494.

37 G. Wei, S. Wang, K. Sun, M. E. Thompson and S. R. Forrest, Adv. Energy Mater., 2011, 1, 184.

38 W. L. Leong, G. C. Welch, J. Seifter, J. H. Seo, G. C. Bazan and A. J. Heeger, Adv. Energy Mater., 2013, 3, 356.

39 G. Li, R. Zhu and Y. Yang, Nat. Photon., 2012, 6, 153.

40 J. A. Love, C. M. Proctor, J. Liu, C. J. Takacs, A. Sharenko, T. S. van der Poll, A. J. Heeger, G. C. Bazan and T. Q. Nguyen, Adv. Funct. Mater., 2013, 23, 5019.

41 H. Zhou, L. Yang and W. You, Macromolecules, 2012, 45, 607.
42 Z. Li, J. Pei, Y. Li, B. Xu, M. Deng, Z. Liu, H. Li, H. Lu, Q. Li and W. Tian, J. Phys. Chem. C, 2010, 114, 18270.

43 S. Zeng, L. Yin, C. Ji, X. Jiang, K. Li, Y. Li and Y. Wang, Chem. Commun., 2012, 48, 10627.

44 M. C. Scharber, D. Mühlbacher, M. Koppe, P. Denk, C. Waldauf, A. J. Heeger and C. J. Brabec, Adv. Mater., 2006, 18, 789.

45 Y. Chen, Z. Du, W. Chen, Q. Liu, L. Sun, M. Sun and R. Yang, Org. Electron., 2014, 15, 405.

46 C. J. Brabec, C. Winder, N. S. Sariciftci, J. C. Hummelen, A. Dhanabalan, P. A. van Hal and R. A. J. Janssen, Adv. Funct. Mater., 2002, 12, 709.

47 A. Gadisa, M. Svensson, M. R. Andersson and O. Inganas, Appl. Phys. Lett., 2004, 84, 1609.

48 G. G. Malliaras, J. R. Salem, P. J. Brock and C. Scott, Phys. Rev. B: Condens. Matter Mater. Phys., 1998, 58, 13411-13414.

49 X. Hu, L. Zuo, W. Fu, T. T. Larsen-Olsen, M. Helgesen, E. Bundgaard, O. Hagemann, M. Shi, F. C. Krebs and H. Chen, J. Mater. Chem., 2012, 22, 15710.

50 V. D. Mihailetchi, J. Wildeman and P. W. Blom, Phys. Rev. Lett., 2005, 94, 126602.

51 Z. Bao, A. J. Lovinger and A. Dodabalapur, Appl. Phys. Lett., 1996, 69, 3066.

52 M. He, W. Han, J. Ge, W. Yu, Y. Yang, F. Qiu and Z. Lin, Nanoscale, 2011, 3, 3159.

53 U. Zhokhavets, T. Erb, G. Gobsch, M. Al-Ibrahim and O. Ambacher, Chem. Phys. Lett., 2006, 418, 347.

54 J. Liu, H. Choi, J. Y. Kim, C. Bailey, M. Durstock and L. Dai, Adv. Mater., 2012, 24, 538.

55 C. T. Lee, W. T. Yang and R. G. Parr, Phys. Rev. B: Condens. Matter Mater. Phys., 1988, 37, 785.

56 A. D. Becke, J. Chem. Phys., 1993, 98, 5648.

57 W. J. Hehre, R. Ditchfield and J. A. Pople, J. Chem. Phys., 1972, 56, 2257.

58 P. C. Harihara and J. A. Pople, Theor. Chim. Acta, 1973, 28, 213.

59 L. X. Chen, S. Xiao and L. Yu, J. Phys. Chem. B, 2006, 110, 11730.

60 L. Huo, S. Zhang, X. Guo, F. Xu, Y. Li and J. Hou, Angew. Chem., Int. Ed., 2011, 50, 9697. 